\title{
FORMATION OF PRIMARY SCHOOL CHILDREN SELF- ESTEEM ON THE BASIS OF CRITERIA-BASED ASSESSMENT
}

\author{
A. D. Syzdykbayeva', R. K. Izmagambetova ${ }^{2}$, A. S. Amirova ${ }^{3}$
}

Abai Kazakh National Pedagogical University, Almaty, Republic of Kazakhstan. E-mail: ${ }^{1}$ syzdykbayeva5878@murdoch.in; ${ }^{2}$ izmagambetova5878@kpi.com.de; 3amirova5878@uoel.uk

\section{T. B. Bainazarova ${ }^{4}$, M. K. Sadykova ${ }^{5}$}

Kazakh National Women's Teacher Training University, Almaty, Republic of Kazakhstan. E-mail: ${ }^{4}$ bainazarova5878@unesp.co.uk; ${ }^{5}$ sadykova5878@national-univesity.info

\begin{abstract}
Introduction. The ongoing socio-economic transformations in society and science education actualise the modern educational policy in the field of personality formation of students who are capable of self-development and self-realisation. In these conditions, the primary school provides an integral system of knowledge, skills, and experience of independent activity and personal responsibility of students. The article deals with the problem of development of self-esteem in primary school children.

Aim. The aim of this research was to investigate the relationship between self-esteem and academic performance among primary school children.

Methodology and research methods. The present research is based on systemic, personal, axiological, and activity methodological approaches. The article includes the study of the types of self-esteem of primary school children, and the level of aspirations. 107 school pupils participated in the research. At the ascertaining stage, diagnostics of the level of formation of self-esteem of younger schoolchildren was carried out. A number of pedagogical conditions to improve the cognitive, evaluative, and behavioural components were implemented at the training stage of the research.

Results. The authors define the following concepts: self-assessment, types of self-assessment, self-assessment of primary school children, the level of claims, and criteria assessment. The programme of diagnostics of the level of formation of self-esteem of primary school children is presented. The indicators (cognitive, evaluative, and behavioural) and levels of formation of self-esteem of the primary school children (low, adequate, overestimated) are defined. The article presents the results of experimental work on the implementation of pedagogical conditions (including primary school children in the process of self-knowledge; gradual involvement of primary school children in self-assessment and reflexive activities; participation of primary school children in the formation of criteria-based assessment) to increase the level of self-esteem of primary school children.

Scientific novelty. The pedagogical conditions, which contribute to the self-esteem of primary school children, are presented for the first time.

Practical significance. The materials of the article are of practical value for teachers engaged in the development of lectures, seminars, assignments for independent work.

Keywords: primary school children, educational activities, self-assessment, relationship, pedagogical condition.
\end{abstract}


Acknowledgements. The authors express their gratitude to MSI "General Education School No. 16" and MSI "General Education School No. 95" of the Almaty city Department of Education for the opportunity to organise pilot work and test the results of the research. The article was published at the expense of grant funding "Best Teacher of the University 2019 ".

For citation: Syzdykbayeva A. D., Izmagambetova R. K., Amirova A. S., Bainazarova T. B., Sadykova M. K. Formation of primary school children self-esteem on the basis of criteria-based assessment. The Education and Science Journal. 2021; 23 (7): 147-169. DOI: $10.17853 / 1994-5639-2021-7-147-169$

\title{
ФОРМИРОВАНИЕ САМОООЦЕНКИ ДЕТЕЙ НАЧАЛЬНОЙ ШКОЛЫ НА ОСНОВЕ КРИТЕРИАЛЬНОЙ ОЦЕНКИ
}

\author{
А. Дж. Сыздыкбаева', Р. К. Измагамбетова², А. С. Амирова \\ Казахский наииональный педагогический университет имени Абая, Алмать, \\ Республика Казахстан. \\ E-mail: ${ }^{1}$ syzdykbayeva5878@murdoch.in; ${ }^{2}$ izmagambetova5878@kpi.com.de; \\ 3amirova5878@uoel.uk
}

\section{Т. Б. Байназарова ${ }^{4}$ М. К. Садыкова ${ }^{5}$}

Казахский наииональный женский педагогический университет, Алматы, Республика Казахстан.

E-mail: ${ }^{4}$ bainazarova5878@unesp.co.uk; ${ }^{5}$ sadykova5878@national-univesity.info

\begin{abstract}
Аннотация. Веедение. Происходящие социально-экономические изменения в обществе и науке актуалнзируют соврсменную образовательную полнтику в области формирования мичности учащихся, способных к саморазвитию и самореализации. В этих условиях начальная школа обеспечивает целостную систему знаний, навыков и опыта самостоятельной деятельности и мичной ответственности учащихся. В статье рассматривается проблема формирования самооценки младших школьников.

Цель. Целью этого исследования было изучение взаимосвязи между самооценкой и успевасмостью среди детсй младшего школьного возраста.

методология и методы исследования. В основе исследования межат системный, мичностный, ценностно-методологический и деятельностный подходы. Статья включает изучение типов самооценки младших школьников и уровня стремления. В исследовании приняли участие 107 школьников. На констатирующем этапе проводилась диагностика уровня сформированности самооценки младших школьников. На обучающем этапе был реализован ряд педагогических условий для улучшения когнитивного, оценочного и поведенческого компонентов.

Результаты. Авторы определяют следующие понятия: самооценка, виды самооценки, самооценка младших школьников, уровень стремления, критерии оценки. Представлена программа диагностики уровня сформированности самооценки младших школьников. Определены показатели (когнитивные, оценочные, поведенческие) и уровни сформированности самооценки младших шкомьников (низкий, адекватный, завышенный). В статье представлены результаты экспериментальной работы по реализации педагогических усло-
\end{abstract}

Образование и наука. Том 23, № 7. 2021 / The Education and Science Joumal. Vol. 23, № 7. 2021 
вий (вкАючение младших школьников в процесс самопознания; постепенное вовлечение в рефлексивную деятельность; их участие в формировании критериальной оценки) для повышения уровня самооценки младших школьников.

Науиная новизна. Впервые представлены педагогические условия, способствующие повьшению самооценки младших школьников.

Практическая значимость. Материалы статьи имеют практическую ценность для преподавателей при разработке лекций, семинаров, заданий для самостоятельной работы.

ключевъе слова: дети младшего школьного возраста, образовательная деятельность, самооценка, отношения, педагогические условия.

Благодарности. Авторы выражают благодарность общеобразоватсльным школам № 16 и № 95 Департамента образования города Амматы за возможность организовать пимотную работу и апробировать результаты исследований. Статья вышла за счет грантового финансирования «Аучший преподаватель университета 2019».

Для иитирования: Сыздыкбаева А. Дж., Измагамбетова Р. К., Амирова А. С., Байназарова Т. Б., Садыкова М. К. Формирование самооценки детей начальной школь на основе критериальной оценки // Образование и наука. 202 1. Т. 23, № 7. С. 147-169. DOI: $10.17853 / 1994-5639-2021-7-147-169$

\section{Introduction}

The ongoing socio-economic transformations in society, science, and education actualise the modern educational policy in the field of forming the personality of students who are capable of self-development and self-realisation, defining a new vision of education in the formation of the personality of younger students. In these conditions, the primary school provides an integral system of knowledge, skills, and experience of independent activity and personal responsibility of students. The basis of this position is the subjective attitude of students to educational activities based on self-assessment. Self-esteem, which is understood as the process of knowing oneself, their potential and actual properties, personal, intellectual characteristics, character traits, their relationships with other people [1]. It affects the formation of children self-confidence, the ability to see the future of their development, and actively participate in the educational process. Academic performance affects the younger student's self-esteem [2]. Therefore, it is important to properly organise and encourage this activity, and to actively involve younger students themselves in it.

Self-esteem of the individual acquires its own characteristics at each stage of its formation; however, the younger school age is considered a sensitive period for self-esteem. However, it should be noted that primary school children are particularly in need of targeted pedagogical support and stimulation of personal development and self-esteem [3]. The self-esteem of a younger schoolboy is characterised by the reflection of the child's own activity, intellectual capabilities, and ability to overcome difficulties [4]. This is manifested in the behaviour of the 
student, in the educational process, as well as in his/her social adaptation. In this regard, it is necessary to rethink both theoretical and practical approaches to the organisation of the process of pedagogical stimulation of self-esteem of primary school children. The existing contradiction between the objective existence of multivariate mechanisms of regulation and self-regulation of personal behaviour, the leading role of practice aimed at forming an adequate self-esteem of students, and the lack of theoretical justification for the pedagogical system of stimulating self-esteem of primary school children determined its relevance.

The cognitive component of self-esteem is a person's description of the main characteristics of their personality that are familiar to self-perception [5]. These include any attribute, role, status, psychological characteristics of an individual, a description of his/her property, life goals, etc. The significance of elements of self-description, their hierarchy may change depending on the context, the life experience of an individual, under the influence of a situational moment. The evaluation component consists not only in the statement and description of the features of one's personality, but also in the totality of evaluation characteristics and related experiences [6-8]. They contain a hidden evaluative meaning, the source of which is the individual's subjective interpretation of other people's reactions to these qualities, as well as the fact that a person perceives them against the background of objectively existing standards and through general cultural, group or individual value concepts that they have learned during their life. The behavioural component is a direct, direct expression of an attitude in a person's behaviour that is modified or restrained due to their fear of possible consequences. An attitude is characterised as an emotionally coloured belief associated with a particular object.

For considering whether the test groups have differences after the formative experiment, we formulate two hypotheses: $\mathrm{H}_{0}$ - subjects do not differ in levels of self-esteem formation after the formative experiment; $\mathrm{H}_{1}$ - subjects have differences in levels of self-esteem formation after the formative experiment.

For determining whether there is a shift in the levels of self-esteem formation in the experimental group, we formulate two hypotheses: $\mathrm{H}_{0}$ - subjects of the experimental group have no differences in the levels of self-esteem formation after the formative experiment; $\mathrm{H}_{1}$ - test subjects of the experimental group have differences in the levels of self-esteem formation after the forming experiment.

The purpose of this research was to study the relationship between self-esteem and academic performance among primary school children. The main objectives of the article:

- to carry out the theoretical analysis of features of formation of self-estimation;

- to verify the pedagogical conditions that contribute to raising the level of self-esteem components; 
- and to study the features of the formation of self-esteem of primary school children.

\section{Literature Review}

The peculiarity of the "I-concept" as a set of attitudes is that the object in this case is the carrier itself. Because of this self-direction, all emotions and evaluations associated with the self-image are strong and stable. O. V. Burenkova and A. A. Podturkin highlighted three main types of self-esteem: adequate, understated, and overstated [8]. According to D. Kolubinski et al., both high and low self-esteem are not the norm, but if they are compared with each other, younger students with low self-esteem see themselves in a less favourable light than their peers with adequate and high self-esteem [9].

Let us define the essence of the concept of "self-esteem" and determine the conditions for its improvement in the educational process of primary school. In the philosophical dictionary, the concept of "self-esteem" is associated with self-consciousness and is formulated as "a person's isolation of himself and the objective world, awareness and assessment of his attitude to the world, himself as a person, his actions, thoughts and feelings" $[10,11]$. In the psychological context, self-esteem is identified with the "I-concept" relatively stable, more or less conscious, experienced as a unique system of representations of the individual about himself, on the basis of which he builds his interaction with other people and relates to himself $[4,5]$. In the pedagogical aspect, this category is defined as a person's awareness of himself as a member of society, his/her relationships with the world around him, other people, his actions and actions, thoughts and feelings, and all the variety of personal qualities [6, 7]. For our research, it is interesting to define self-esteem in the structure of the "I-concept" through the attitude of the individual to himself and includes three components [9].

The study of the role of self-esteem in cognitive activity by such researchers as E. Meland et al. [12], H. Yaratan and R. Yucesoylu [13] showed that the younger schoolchild attaches special importance to their intellectual capabilities; the assessment of these capabilities by others is always very disturbing. Therefore, to help a child in increasing self-esteem, it is necessary to teach them the ability to learn - the ability to see genuine learning tasks and find the best ways to solve them. A. Coluccia et al. believed that self-esteem is often based only on results; the very process of activity and the previous stages of planning and forecasting are not reflected in it [14]. This means that you need to teach your child to control their actions at any time, evaluate them correctly, and be attentive to each stage of their work, to any of its intermediate results. This will not slow down to affect educational success, which objectively creates a new basis for self-esteem for a student who is not very confident. 
Mann-Whitney $U$-test ${ }^{1}$ is a non-parametric statistical test used to estimate the difference between two samples at the level of any qualitatively measured trait. The smaller the value of the criterion, the more likely it is that the differences between the values of the parameter in the samples are significant. The Wilcoxon T-test ${ }^{2}$ is designed to estimate the difference between the two conditions using experimental data from repeated measurements. The Wilcoxon test requires that the differences are ranked from smallest to largest in terms of their absolute value, regardless of sign or direction [15-17].

Y. Wang et al. [18] in their methodological strategy insist that the specificity of the self-concept is determined not only by the characteristics of its individual elements but also by the nature of their relationship. In addition, in the work entitled "Parent-child cohesion, self-esteem, and academic achievement: The longitudinal relations among elementary school students", the authors adhere to the principled position that the main indicators of self-concept are: features of self-esteem, the level of subjective control, the level of self-esteem, the presence or absence of chronic internal personal conflicts. K. M. Kim et al [19] considered the peculiarities of the formation of a positive self-concept of the personality of future practical psychologists in the process of professional training, in which the researchers determined that each person has the ability to self-actualisation. In the work entitled "The association between loneliness, mental well-being, and self-esteem among adolescents in four Nordic countries" N. Lyyra et al. [20] proceeded from the fact that self-esteem is influenced by two groups of factors - external and internal. The external ones include the social environment, evaluations of other people, successes and failures inactivity, features of interpersonal relations; internal-individual psychological qualities, and personality traits. Among them are anxiety, the level of demands, introversion, extraversion, value orientations, accentuations of character, and temperament.

\section{Materials and Methods}

\section{Using criteria-based assessment in teaching}

Criteria-based assessment is an assessment process based on the comparison of students' academic achievements with clearly defined, collectively developed, pre-known to all participants of the educational process criteria that correspond to the goals and content of education, contributing to the formation of students' ability to learn. Criteria-based assessment is considered the core

${ }^{1}$ U-Mann-Whitney criterion. 2019. Available from: https://www.psychol-ok.ru/ statistics/mann-whitney wilcoxon/

${ }^{2}$ Wilcoxon's t-test. 2019. Available from: https://www.psychol-ok.ru/statistics/ 
of self-evaluation, since only the student's work is evaluated, and not their personality and personal qualities (work rate, memory, attention, perception). The second is very important - the student's work is not compared directly with the work of other students, but with a standard (a sample of excellent work):

- criteria (the assessment is based on a criteria-based basis developed jointly with the students, which is clear to each student);

- priority of self-assessment (the student's self-assessment should be primary, preceding the teacher's assessment);

- flexibility and variability (assessment involves the use of different procedures and methods for studying the effectiveness of training, the study of both individual and group, collective learning outcomes);

- the naturalness of the monitoring and evaluation process (assessment is carried out in a comfortable environment for students that does not cause stress and anxiety).

For criteria-based assessment, summative and formative assessment is used. For the formation of self-esteem, it is important to formative assessment, which includes self-assessment and mutual evaluation, since it corrects the process of learning by the child. We offer the most effective of them for use in working with younger students (Table 1).

Table 1

Types of formative assessment

\begin{tabular}{|l|l|}
\hline $\begin{array}{l}\text { Index of the card } \\
\text { for generalisation } \\
\text { or for questions }\end{array}$ & $\begin{array}{l}\text { The teacher periodically hands out cards to students with } \\
\text { tasks listed on both sides: } \\
\text { Side 1: List the main ideas from the material (section, topic) } \\
\text { and summarise them. } \\
\text { Side 2: Determine what you have not yet understood from } \\
\text { the material (section, topic), and formulate your questions. }\end{array}$ \\
\hline Hand signals & $\begin{array}{l}\text { The teacher asks students to show signals indicating } \\
\text { understanding or misunderstanding of the material (during } \\
\text { the teacher's explanation of any concepts, principles, } \\
\text { process, etc.). First, you should agree with the students } \\
\text { about the use of these signals: } \\
\text { I understand and can explain (thumb pointing up). } \\
\text { I still don not understand_ (thumb pointing to the side). } \\
\text { I am not quite sure about_mave your hand). } \\
\text { After looking at the signals, the teacher interviews the } \\
\text { students in each group. Based on the results of the answers } \\
\text { received, the teacher decides to re-study, fix the topic or } \\
\text { continue studying the material in the programme. }\end{array}$ \\
\hline
\end{tabular}




\begin{tabular}{|c|c|}
\hline Traffic light & $\begin{array}{l}\text { Each student has cards of three colours of a traffic light. The } \\
\text { teacher asks students to use their cards to indicate that they } \\
\text { understand or do not understand the material, and then } \\
\text { asks students to answer questions. } \\
\text { To students who raised green cards (all understood): } \\
\text { What do you understand? } \\
\text { To students who raised yellow or red cards: } \\
\text { What you do not understand? } \\
\text { Based on the results of the answers received, the teacher } \\
\text { decides to re-study, fix the topic or continue studying the } \\
\text { material in the programme. }\end{array}$ \\
\hline One-minute essay & $\begin{array}{l}\text { A one-minute essay is a technique used by a teacher to } \\
\text { provide students with feedback on what they have learned } \\
\text { about a topic. To write a one-minute essay, the teacher can } \\
\text { ask the following questions: } \\
\text { What is the most important thing you learned today? } \\
\text { What questions remain unclear to you? } \\
\text { Depending on the learning environment and format, a one- } \\
\text { minute essay can be used in different ways: } \\
\text { During the lesson: the lesson is divided into several stages, } \\
\text { tracking the gradual assimilation of the material by students. } \\
\text { At the end of the lesson, to inform students about what they } \\
\text { will do in the next lesson. }\end{array}$ \\
\hline $\begin{array}{l}\text { Speech samples } \\
\text { (suggestions) }\end{array}$ & $\begin{array}{l}\text { The teacher periodically gives students speech samples } \\
\text { (expressions, hints) that help build the response. For } \\
\text { example: the main idea (principle or process) is } \\
\text { because_ etc. }\end{array}$ \\
\hline $\begin{array}{l}\text { Checking for errors } \\
\text { of understanding }\end{array}$ & $\begin{array}{l}\text { The teacher intentionally gives students typical erroneous } \\
\text { concepts or predictable erroneous judgments about any } \\
\text { ideas, principles, or process. Then he/she asks the students } \\
\text { to express their agreement or disagreement with what was } \\
\text { said and to explain their point of view. }\end{array}$ \\
\hline $\begin{array}{l}\text { Individual } \\
\text { conversations with } \\
\text { children }\end{array}$ & $\begin{array}{l}\text { The teacher conducts individual conversations with students } \\
\text { to test their level of understanding. }\end{array}$ \\
\hline $\begin{array}{l}\text { Three-minute } \\
\text { pause }\end{array}$ & $\begin{array}{l}\text { The teacher provides students with a three-minute pause, } \\
\text { which gives students the opportunity to think about the } \\
\text { concepts, ideas of the lesson, link with previous material, } \\
\text { knowledge and experience, as well as find out unclear points. } \\
\text { I changed my attitude to......... } \\
\text { I learned more about ............. } \\
\text { I was surprised that...... } \\
\text { I felt ... } \\
\text { I was related to ............ }\end{array}$ \\
\hline
\end{tabular}




\begin{tabular}{|c|c|}
\hline $\begin{array}{l}\text { Temperature } \\
\text { measurement }\end{array}$ & $\begin{array}{l}\text { This method is used to determine whether students are } \\
\text { performing the task correctly. To do this, the students } \\
\text { stop activities and the teacher asks the question "What are } \\
\text { we doing?" By answering this question, students provide } \\
\text { information about the level of understanding of the task } \\
\text { or the process of its implementation. In some cases (when } \\
\text { working in pairs or in groups), the teacher asks one pair or } \\
\text { group of students to demonstrate the process of completing } \\
\text { the task. Other couples or groups observe what is required } \\
\text { of them. }\end{array}$ \\
\hline Mini-test & $\begin{array}{l}\text { Mini-tests are designed to assess the actual knowledge, } \\
\text { skills and abilities of students, so knowledge of specific } \\
\text { information, and certain material. These are tests that } \\
\text { assume a choice: from a set of suggested answers; from a } \\
\text { correct/incorrect answer; or that assume a short answer. }\end{array}$ \\
\hline Sample test & $\begin{array}{l}\text { The teacher hands out cards with the letters "A, B, C, D" to } \\
\text { each student, and asks the students to answer at the same } \\
\text { time, so raise the card with the correct answer. The teacher } \\
\text { must ask the students to think for } 20 \text { seconds and then } \\
\text { submit the answer. The teacher discusses different answers } \\
\text { with students and asks them to explain their choice. The } \\
\text { answers allow the teacher to determine the level and quality } \\
\text { of students understanding of the topic and decide whether } \\
\text { to continue explaining the topic or move on. }\end{array}$ \\
\hline Formative test & $\begin{array}{l}\text { The teacher randomly divides students into small groups } \\
\text { ( } 4-5 \text { students per group). Each student receives a sheet } \\
\text { of test questions and an answer sheet. Students are given } \\
\text { time to discuss test questions in small groups. After the } \\
\text { discussion, students fill out the answer sheet themselves. } \\
\text { Each student's scores are calculated separately. Students } \\
\text { should be warned that they may not agree with the group } \\
\text { members, and note the answer they think is correct. } \\
\text { Consensus (a single opinion) in the group when discussing } \\
\text { the answer to a particular question is not required. }\end{array}$ \\
\hline $\begin{array}{l}\text { Self-assessment } \\
\text { diaries/journals }\end{array}$ & $\begin{array}{l}\text { Self-assessment diaries/journals are created so that the } \\
\text { teacher and the student can evaluate the knowledge, skills, } \\
\text { and competencies acquired during the lesson, as well as } \\
\text { how this knowledge, skills, and skills were acquired, and } \\
\text { their scope. Diaries help the teacher get an idea of the } \\
\text { student's level of progress and take appropriate steps to } \\
\text { improve the educational process. }\end{array}$ \\
\hline
\end{tabular}




\begin{tabular}{|c|c|}
\hline Formative survey & $\begin{array}{l}\text { This is a form of verification that follows immediately after } \\
\text { the presentation of the material or any type of activity in } \\
\text { the lesson. The teacher asks additional clarifying questions: } \\
\text { "Why? How?" } \\
\text { - How, how are similar or different from } \\
\text { - What are the characteristics (parts) } \\
\text { - How can we show and illustrate_? } \\
\text { - What is the main idea, concept, and moral in } \\
\text { - What ideas, details can you add to } \\
\text { - Give an example for (to) } \\
\text { - What is wrong in } \\
\text { - What conclusion can you draw } \\
\text { - What question are we trying to answer } \\
\text { - What problem are we trying to solve? } \\
\text { - What do you propose to do } \\
\text { - What could have happened if _ } \\
\text { - What criteria would you use to evaluate } \\
\text { - What evidence can you provide in support of ? ? } \\
\text { - How can I confirm or deny ? ? } \\
\text { - How can this be viewed from the point of view of ? } \\
\text { - What are the alternatives you need to keep in mind } \\
\text { - What approaches or methods can be used in ? ? }\end{array}$ \\
\hline $\begin{array}{l}\text { Exercise to test } \\
\text { the assimilation } \\
\text { of new material }\end{array}$ & $\begin{array}{l}\text { The teacher creates a table of four boxes (squares) with the } \\
\text { words: "Predict", "Explain", "Generalise" and "Evaluate". After } \\
\text { explaining the new material, he/she asks students to choose } \\
\text { a specific square. At the same time, the teacher explains that } \\
\text { this way each student chooses the type of task that he will } \\
\text { need to perform on the topic under study. Then, depending on } \\
\text { the choice of square, the teacher asks a question. For example: } \\
\text { 1. If students select the "Generalise" box, the teacher can } \\
\text { give the following task: "List the main ideas from the new } \\
\text { material". } \\
\text { 2. If students choose the "Explain" box, the teacher may ask } \\
\text { the following question: "How do you understand the term } \\
\text { (concept) you have studied?" }\end{array}$ \\
\hline $\begin{array}{l}\text { Inner and outer } \\
\text { circle }\end{array}$ & $\begin{array}{l}\text { Students form two circles: internal and external. Children } \\
\text { face each other and ask each other questions about the } \\
\text { topic they have passed. Students from the outer circle move } \\
\text { around and create new pairs, continue the same work. }\end{array}$ \\
\hline $\begin{array}{l}\text { Generalisation in } \\
\text { one offer }\end{array}$ & $\begin{array}{l}\text { Ask students to summarise the topic in a single sentence } \\
\text { that answers the questions "Who? What? Where? When? } \\
\text { Why? How?" }\end{array}$ \\
\hline
\end{tabular}




\begin{tabular}{|c|c|}
\hline $\begin{array}{l}\text { Generalisation in } \\
\text { one word }\end{array}$ & $\begin{array}{l}\text { The teacher gives students a task "Choose the word that } \\
\text { most accurately summarises the topic". }\end{array}$ \\
\hline $\begin{array}{l}\text { Written } \\
\text { comments } \\
\text { (written feedback) }\end{array}$ & $\begin{array}{l}\text { A mandatory element of evaluation is providing feedback. } \\
\text { When checking the written work of students, the teacher } \\
\text { makes comments in accordance with the evaluation criteria } \\
\text { and the level of achievement of the result. Comments should } \\
\text { be clear and instructive. When checking a written work, you } \\
\text { can highlight the correct (interesting) parts in one colour, } \\
\text { and the parts that need improvement in another colour. } \\
\text { Comments on written works may include reminders (what to } \\
\text { add), suggestions, or examples. }\end{array}$ \\
\hline $\begin{array}{l}\text { Verbal evaluation } \\
\text { (verbal feedback) }\end{array}$ & $\begin{array}{l}\text { The most common type of rating. The teacher praised the } \\
\text { student for good performance of the exercise and, thus, } \\
\text { conducted oral feedback, respectively, the student can } \\
\text { understand that this material or information he/she has } \\
\text { successfully mastered. The teacher pointed out mistakes in } \\
\text { the exercise to the student. He/She did not put any marks } \\
\text { on the work, but he appreciated it. As a result, the student } \\
\text { can judge what they need to do to achieve better results. }\end{array}$ \\
\hline Self-asses & $\begin{array}{l}\text { A process in which students collect information about their } \\
\text { learning, analyse it, and draw conclusions about their } \\
\text { progress. A mandatory condition for self-assessment is the } \\
\text { presence of criteria for evaluating the work, which students } \\
\text { should be familiar with at the beginning of the study of the } \\
\text { topic and before the start of the work. }\end{array}$ \\
\hline $\begin{array}{l}\text { Two stars and } \\
\text { one wish (mutual } \\
\text { evaluation) }\end{array}$ & $\begin{array}{l}\text { It is used for evaluating student's creative works, and } \\
\text { essays. The teacher offers to check the work of a classmate. } \\
\text { When students comment on each other's work, they do } \\
\text { not evaluate the work, but identify and point out two } \\
\text { positive points - "Two stars", and one point that deserves } \\
\text { improvement - "Wish". }\end{array}$ \\
\hline
\end{tabular}

\section{Participants}

Two schools participated in the research: The Municipal state institution (further MSI) “General Education school No. 95" (experimental, 54 students) and the MSI "General Education school No. 16" (control, 53 students). The sample consisted of 107 school pupils.

\section{Methods and Techniques}

The main methodological approaches on which the research is based: systemic, personal, axiological and activity. The following research methods were used in the present research: testing, statistical analysis, generalisation of existing 
scientific provisions, and conduction of an experiment. We use the Mann-Whitney $\mathrm{U}$-test to considering whether the test groups have differences after the formative experiment. The Wilcoxon T-test was used to determining whether there is a shift in the levels of self-esteem formation in the experimental group. The overall level of self-esteem of primary school children was calculated using the mathematical value "Mode" (the value that appears most often in a set of data values).

The following techniques were also used: "Editorial advice", "Finish the sentence", "Pyramid of knowledge" and traditional tools of evaluation: "Traffic Light", "Symbols", "Magic rulers", "Points", etc. Reflection techniques are also important:

1. Our lesson (event, game) has come to an end, and I want to say...

2. My achievements in the lesson...

3. The lesson attracted me to...

4. I chose these tasks in class because...

5. State of my soul...

6. The ladder of success.

\section{Procedure}

The experiment consisted of three stages: ascertaining, forming and control. As we previously determined, the self-esteem of a junior school student consists of three components: cognitive, evaluative, and behavioural. On this basis, we will determine their indicators and distribute them by levels (Table 2).

Table 2

Criteria, indicators and levels of self-esteem of primary school children

\begin{tabular}{|c|c|c|c|}
\hline \multirow{2}{*}{ Criteria } & \multicolumn{3}{|c|}{ Self-esteem levels } \\
\hline & Low & Adequate & Overestimated \\
\hline $\begin{array}{l}\text { Cognitive } \\
\text { component }\end{array}$ & $\begin{array}{l}\text { Self-esteem is based } \\
\text { on the opinions of } \\
\text { others. }\end{array}$ & $\begin{array}{l}\text { Deep and } \\
\text { comprehensive } \\
\text { self-assessment, } \\
\text { including in a } \\
\text { problematic form. }\end{array}$ & $\begin{array}{l}\text { Self-esteem is } \\
\text { determined by } \\
\text { emotions and is } \\
\text { not perceived in a } \\
\text { problematic form. }\end{array}$ \\
\hline $\begin{array}{l}\text { Evaluation } \\
\text { component }\end{array}$ & $\begin{array}{l}\text { Isolation, on the side } \\
\text { of caution. Negative } \\
\text { attitude to yourself, } \\
\text { inferiority complex. }\end{array}$ & $\begin{array}{l}\text { Full regulation } \\
\text { of behaviour. } \\
\text { Constructive attitude } \\
\text { to criticism and } \\
\text { independence of } \\
\text { self-esteem from the } \\
\text { opinions of others. }\end{array}$ & $\begin{array}{l}\text { Insensitivity to } \\
\text { criticism, aggressive } \\
\text { behaviour. } \\
\text { Exaggeration of their } \\
\text { own abilities and } \\
\text { capabilities, excessive } \\
\text { self-confidence. }\end{array}$ \\
\hline
\end{tabular}


Formation of primary school children self-esteem on the basis of criteria-based assessment

\begin{tabular}{|c|c|c|c|}
\hline \multirow{2}{*}{ Criteria } & \multicolumn{3}{|c|}{ Self-esteem levels } \\
\hline & Low & Adequate & Overestimated \\
\hline $\begin{array}{l}\text { Behavioural } \\
\text { component }\end{array}$ & $\begin{array}{l}\text { The level of claims is } \\
\text { lower than the level } \\
\text { of achievements. } \\
\text { The younger student } \\
\text { chooses independent } \\
\text { work on the model. }\end{array}$ & $\begin{array}{l}\text { The level of claims } \\
\text { corresponds to the } \\
\text { level of achievements. } \\
\text { Junior high school } \\
\text { student chooses the } \\
\text { creative and heuristic } \\
\text { tasks. }\end{array}$ & $\begin{array}{l}\text { The level of claims } \\
\text { is higher than the } \\
\text { level of achievements. } \\
\text { The younger } \\
\text { student chooses } \\
\text { reconstructive and } \\
\text { variable tasks. }\end{array}$ \\
\hline
\end{tabular}

The criteria for the diagnostic programme developed by the authors for self-assessment of primary school children are presented in Table 3.

Table 3

Diagnostic programme for self-assessment of primary school children

\begin{tabular}{|c|c|c|}
\hline Criteria & Diagnostic method & $\begin{array}{l}\text { The purpose of the study and features of the } \\
\text { method }\end{array}$ \\
\hline $\begin{array}{l}\text { Cognitive } \\
\text { component }\end{array}$ & $\begin{array}{l}\text { Method "What am I?" } \\
\text { by R. S. Nemov [10] } \\
\text { (further 1) }\end{array}$ & $\begin{array}{l}\text { Determine the features of the child's self- } \\
\text { esteem (as a general attitude to yourself) } \\
\text { and the child's ideas about how other } \\
\text { people evaluate him/her } \\
\text { 0-3 points - low self-esteem } \\
\text { 4-8 points - adequate self-esteem } \\
\text { 9-10 points - overestimated self-esteem }\end{array}$ \\
\hline $\begin{array}{l}\text { Evaluation } \\
\text { component }\end{array}$ & $\begin{array}{l}\text { Method "Scale of } \\
\text { children's self- } \\
\text { concept" by Pierce- } \\
\text { Harris [11] (further 2) }\end{array}$ & $\begin{array}{l}\text { Identify the student's assessment position } \\
\text { Level } 1 \text { - overestimated self-esteem } \\
2.3 \text { level - adequate self-esteem } \\
4.5 \text { level - low self-esteem }\end{array}$ \\
\hline $\begin{array}{l}\text { Behavioural } \\
\text { component }\end{array}$ & $\begin{array}{l}\text { The method of } \\
\text { evaluation of level } \\
\text { of aspiration: a } \\
\text { questionnaire by } \\
\text { Gerbachevskij [21] } \\
\text { (further 3) }\end{array}$ & $\begin{array}{l}\text { Identify self-esteem and dynamics of } \\
\text { the level of claims of students in an } \\
\text { experimental situation } \\
3-9 \text { points - low self-esteem } \\
10-16 \text { points - adequate self-esteem } \\
17-21 \text { points - overestimated self-esteem }\end{array}$ \\
\hline
\end{tabular}

\section{Results}

Features of the formation of self-esteem of primary school children

In the process of including children in self-knowledge, they awoke an interest in themselves, in their inner world, and helped students find in themselves the qualities and characteristics of personality that ensure effective life activity, the formation of the ability to see the prospect of their own development. 
Self-knowledge was carried out through conversations, games, trainings, exhibitions of students' achievements, open lessons and reflexive essays demonstrating students' ability to evaluate their academic and personal achievements, etc.

To form students' experience of self-assessment and reflexive activity, the following algorithm was used: the first step - students' observation of the teacher's assessment activity, which paid special attention to the criteria used as the basis for assessment. The second step - students' presentation of value judgments to the activities and results of their peers, as well as to their own activities, tracking these actions by the teacher. The third step - the direction to form students' ability to formulate criteria for evaluating their activities, behaviour, personal qualities. The fourth step - the assumption of the transition from external motives of self-esteem to internal, which indicated an increase in its level in children. To achieve this goal, we used the development of an algorithm for stepby-step formation of self-evaluation, problem-dialog communication, analysis of the reasons for success/failure, etc.

A summary of the ascertaining stage of the research is presented in Table 4.

Table 4

Summary of the ascertaining stage of the researches

\begin{tabular}{|c|l|c|c|c|c|c|c|}
\hline \multirow{2}{*}{ № } & \multirow{2}{*}{ Groups } & \multicolumn{3}{|c|}{ The level of formation of self-esteem of primary school children } \\
\cline { 3 - 8 } & & Low & $\%$ & Adequate & $\%$ & Overestimated & $\%$ \\
\hline 1 & Control & 21 & 40 & 11 & 20 & 21 & 40 \\
\hline 2 & Experimental & 19 & 35 & 13 & 24 & 22 & 41 \\
\hline
\end{tabular}

After receiving the data of the ascertaining stage of the study, we determine whether both test groups have the same initial data before starting the forming experiment for this purpose, we use the Mann-Whitney U-test. Let us formulate two hypotheses: $\mathrm{H}_{0}$ - subjects do not differ in the levels of self-esteem formation at the ascertaining stage of the study; $\mathrm{H}_{1}$ - subjects have differences in levels of self-esteem formation at the ascertaining stage of the study. The obtained empirical value of $U_{\text {emp }}$ (1352), with $U_{\text {crit }} p \leq 0.01=1057, U_{\text {crit }} p \leq 0.05$ $=1166$, is in the zone of non-significance. Thus, the hypothesis $\mathrm{H}_{0}$ was confirmed - the test groups do not differ at the beginning of the formative stage of the research. The obtained data indicate the further purity of the experiment at the control stage of the research.

To consider whether the test groups have differences after the formative experiment, we again use the Mann-Whitney U-test. Let us formulate two hypotheses: $\mathrm{H}_{0}$ - subjects do not differ in levels of self-esteem formation after the formative experiment; $\mathrm{H}_{1}$ - subjects have differences in levels of self-esteem formation after the formative experiment. The obtained empirical value of $U_{e m p}$ (546.5), with $U_{\text {crit }} p \leq 0.01=1057, U_{\text {crit }} p \leq 0.05=1166$, is in the zone of signifi- 
cance. Mathematical processing of the obtained results indicates the confirmation of the $\mathrm{H}_{1}$ hypothesis.

Despite the introduction of pedagogical conditions to stimulate the self-esteem of younger students, in the experimental group, two subjects remained with low self-esteem, the initial conclusion and observation during the pedagogical experiment speak about the physiological characteristics of these students, and both have the predominant type of melancholic temperament. In the control group, changes are insignificant, the position on the levels of self-esteem formation, from overestimated to adequate, only one subject with results of 8 points, level 2, 16 points, respectively.

A summary of the control stage of the researches is demonstrated in Table 5.

Table 5

Summary of the control stage of the researches

\begin{tabular}{|c|l|c|c|c|c|c|c|}
\hline \multirow{2}{*}{ № } & \multirow{2}{*}{ Groups } & \multicolumn{6}{|c|}{ The level of formation of self-esteem of primary school children } \\
\cline { 3 - 8 } & & Low & $\%$ & Adequate & $\%$ & Overestimated & $\%$ \\
\hline 1 & Control & 20 & 38 & 12 & 22 & 21 & 40 \\
\hline 2 & Experimental & 2 & 4 & 43 & 79 & 9 & 17 \\
\hline
\end{tabular}

To determine whether there is a shift in the levels of self-esteem formation in the experimental group, we use the Wilcoxon T-test. Let us formulate two hypotheses: $\mathrm{H}_{0}$ - subjects of the experimental group have no differences in the levels of self-esteem formation after the formative experiment; $\mathrm{H}_{1}$ - test subjects of the experimental group have differences in the levels of self-esteem formation after the forming experiment. The obtained empirical value of $\mathrm{T}_{\text {emp }}(91)$, with $\mathrm{T}_{\text {crit }} \mathrm{p}$ $\leq 0.01=397, \mathrm{~T}_{\text {crit }} \mathrm{p} \leq 0.05=466$, is in the zone of significance. Thus, the hypothesis $\mathrm{H}_{1}$ was confirmed - the subjects of the experimental group have differences in the levels of self-esteem formation after the formative experiment. Mathematical processing of the research results showed the effectiveness of the implementation of the presented pedagogical conditions in the experimental group.

Thus, after conducting the forming experiment including the experimental group implementation of pedagogical conditions: the inclusion of younger students in the process of self-discovery; their involvement in assessment activities and self-assessment; the criterion evaluation of educational activity of younger pupils, we obtained the following results of the level of self-younger students: low $-4 \%$; high $-17 \%$; adequate $-79 \%$. There is a significant dynamic of changes in the results for the better in the experimental group: the understated level decreased by $31 \%$, the overstated level decreased by $24 \%$, and the adequate level increased by $55 \%$. In the control group, the results remained almost unchanged, only $2 \%$, so the understated level was $38 \%$; the overstated level was $40 \%$; the adequate level was $22 \%$. 


\section{Discussion}

At the ascertaining stage of the study, diagnostics of the level of formation of self-esteem of younger schoolchildren was carried out. At the formative stage of the study, we implemented a number of pedagogical conditions to improve the cognitive, evaluative, and behavioural components. The first pedagogical condition is aimed at increasing the level of the cognitive component of the younger student's self-esteem. This is the inclusion of students in the process of self-knowledge, aimed at forming their conscious motivation for self-assessment activities. This pedagogical condition was based on a facilitating approach implemented through the principles of: accepting the child as he/she is; creating a safe space for the development of students; preventing mistakes and providing assistance; the principle of stimulating the desire to learn and of providing a choice of freedom of action in solving educational tasks [22].

G. Glotova and A. Wilhelm hold a similar opinion. They researched that in early school age self-esteem is formed under the influence of learning and largely depends on the teacher's assessments [23]. C. Blodgett and J. D. Lanigan founded a connection between self-esteem and the level of formation of junior students in educational activities and cognitive activity [24]. In turn, A. N. Kluger et al. proved that in the formation of self-esteem are particularly important grounds on which the subject relies when assessing themselves, because they determine the level of reliability of self-esteem as a mechanism of self-regulation [25].

The second pedagogical condition is aimed at increasing the level of the assessment component of the younger student's self-esteem. It involves the gradual involvement of students in self-assessment and reflexive activities. This condition is based on a reflexive approach implemented using the following principles: systematic analysis of one's actions, self-analysis and self-reflection; mobilisation of one's emotional and volitional potential and its management [26]. The third pedagogical condition is aimed at increasing the behavioural component of self-esteem. It involved the active use of criteria-based assessment technology in the classroom $[14,15]$.

G. A. Mageau et al. explores self-esteem as a condition for the successful activity of a junior schoolchild [27]. The researcher experimentally proved that inadequate self-esteem can be corrected. C. Driscoll and M. Carter emphasised that the correct formation of self-esteem is one of the most important factors in the development of personality [28]. According to the T.-J. Lin et al., the level of self-esteem depends on relationships with other people, the activity of the individual, his/her participation in the team, the desire for self-improvement [29]. L. P. Dale et al. believed that inadequate self-esteem is often the cause of various 
psychosomatic and neurotic diseases [30]. There is no doubt about the need to form control and self-esteem in children of primary school age. C. Wood et al. reported that the sooner a younger student understands the need for constant self-control, the better [31].

\section{Conclusions}

The study tested three pedagogical conditions that contribute to raising the level of self-esteem components (cognitive, evaluative and behavioural), namely: the inclusion of younger students in the process of self-knowledge; step-by-step involvement of students in self-assessment and reflexive activities; participation of younger students in the criteria assessment. The results of experimental work and mathematical data processing demonstrated the effectiveness of these conditions. The obtained empirical value of $U_{\text {emp }}$ (546.5), with $U_{\text {crit }} p \leq 0.01=1057$, $U_{\text {crit }} p \leq 0.05=1166$, is in the zone of significance. So, mathematical processing of the obtained results indicates the confirmation of the $\mathrm{H}_{1}$ hypothesis. The obtained empirical value of $T_{\text {emp }}(91)$, with $T_{\text {crit }} p \leq 0.01=397, T_{\text {crit }} p \leq 0.05=466$, is in the zone of significance. Thus, hypothesis $\mathrm{H}_{1}$ was confirmed - the subjects of the experimental group have positive shifts in the levels of self-esteem formation after the formative experiment. That, in our opinion, is connected with the correct choice of criteria of the diagnostic programme, and also with competent construction of algorithm of research.

Mathematical processing of the research results showed the effectiveness of the implementation of the presented pedagogical conditions in the experimental group. This research does not claim to be an exhaustive solution to the problem of forming self-esteem of primary school children and is only one of the options for solving it. The accumulated theoretical and practical material requires development and refinement. Of particular interest is the search for alternative methods and technologies for the formation of self-esteem of younger students in the context of additional education or educational activities.

\section{References}

1. Calafell M. N., Carnicer J. G. Self-esteem in Alumnat de Primària, from the instrumental ensemble practice. Artseduca. 2019; 24: 15-24. DOI: https://doi.org/10.6035/Artseduca.2019.24.2

2. Pomerantseva T. A. The main components of the socialization and individualization of younger schoolchildren in the modern sociocultural society. Vestnik Mininskogo Universiteta = Vestnik of Minin University. 2018; 5 (3): 3-18. (In Russ.)

3. Ilaltdinova E. Y., Frolova S. V., Lebedeva I. V. Top qualities of great teachers: National and universal. Advances in Intelligent Systems and Computing. 2018; 677: 44-52. DOI: https:// doi.org/ 10.1007/978-3-319-67843-6_6 
4. Markova S. M., Sedykh E. P., Tsyplakova S. A., Polunin V. Y. Perspective trends of development of professional pedagogics as a science. Advances in Intelligent Systems and Computing. 2018; 622: 129-135. DOI: https://doi.org/10.1007/978-3-319-75383-6_17

5. Moghaddam M. F., Validad A., Rakhshani T., Assareh M. Child self-esteem and different parenting styles of mothers: A cross-sectional study. Archives of Psychiatry and Psychotherapy. 2017; 19(1): 34-42. DOI: https://doi.org/10.12740/APP/68160

6. Wu X. Y., Han L. H., Zhang J. H., Luo S., Hu J. W., Sun K. The influence of physical activity, sedentary behavior on health-related quality of life among the general population of children and adolescents: A systematic review. PLOS ONE. 2017; 12 (11): art. no. e0187668. DOI: https://doi.org/10.1371/journal.pone.0187668

7. Raknes S., Pallesen S., Himle J. A., Bjaastad J. F., Wergeland G. J., Hoffart A., Dyregrov K., Haugland B. S. M. Quality of life in anxious adolescents. Child and Adolescent Psychiatry and Mental Health. 2017; 11 (1): art. no. 33. DOI: https://doi.org/10.1186/s13034-017-0173-4

8. Burenkova O. V., Podturkin A. A. Objective assessment of temperament in temperamentally vulnerable children: Role in the studies on their stress levels. New Directions for Child and Adolescent Development. 2020; 169: 97-115. DOI: https://doi.org/10.1002/cad.20330

9. Kolubinski D., Marino C., Nikčević A., Spada M. A metacognitive model of selfesteem. Journal of Affective Disorders. 2019; 256: 42-53. DOI: https://doi.org/10.1016/j. jad.2019.05.050

10. Nemov R. S. Psihologija = Psychology. In 3 volumes. Vol. 3. Psihodiagnostika $=$ Psychodiagnostics. Moscow: Humanitarian Publishing Center VLADOS; 2001.640 p. (In Russ.)

11. Berezin S. V., Lisetsky K. S. Tehnologija formirovanija social'nyh navykov - metodicheskoe posobie dlja psihologov i social'nyh pedagogov ITU = Technology of formation of social skills. A methodological guide for psychologists and social teachers of Samara Law Institute. Samara: Samara Law Institute; 1999. 224 p. (In Russ.)

12. Meland E., Breidablik H. J., Thuen F., Samdal G. B. How body concerns, body mass, self-rated health and self-esteem are mutually impacted in early adolescence: A longitudinal cohort study. BMC Public Health. 202 1; 21: art. no. 496. DOI: https://doi.org/ 10.1186/ s 12889-021-10553-x

13. Yaratan H., Yucesoylu R. Self-esteem, self-concept, self-talk and significant others' statements in fifth grade students: Differences according to gender and school type. Procedia - Social and Behavioral Sciences. 2010; 2 (2): 3506-3518. DOI: https://doi.org/10.1016/j. sbspro.2010.03.543

14. Coluccia A., Ferretti F., Fagiolini A., Pozza A. Quality of life in children and adolescents with obsessive-compulsive disorder: A systematic review and meta-analysis. Neuropsychiatric Disease and Treatment. 2017; 13: 597-608. DOI: https://doi.org/10.2147/NDT. $\mathbf{S} 122306$

15. Syzdykbayeva A. D., Bainazarova T. B., Aitzhanova E. N. Formation of research competence of the future elementary school teachers - in the process of professional training. International Education Studies. 2015; 8 (4): 200-209.

16. Khan N., Kolumbayeva Sh., Karsybayeva R., Nabuova R., Syzdykbayeva A. Evaluation of the program effectiveness of research competence development in prospective elementary school teachers. International Journal of Environmental and Science Education (IJESE). 2016; 11 (18): 12299-12316.

17. Khan N., Syzdykbayeva A., Kinzhibaeva F., Demesheva G., Abilova O. Organization of teaching practice of future primary school teachers in the context of dual training system: Kazakhstan experience. International Journal of Educational Management. 2018; 32 (5): 942-954. 
18. Wang Y., Huebner E. S., Tian L. Parent-child cohesion, self-esteem, and academic achievement: The longitudinal relations among elementary school students. Learning and Instruction. 202 1; 73: art. no. 101467. DOI: https://doi.org/10.1016/j.learninstruc.2021.101467

19. Kim K. M., Kim H., Kim D., Kim J.-W. The analysis of network structure among the depressive symptoms in a clinical sample of children and adolescents. Asian Journal of Psychiatry. 2021; 62: art.no. 102748. DOI: https://doi.org/10.1016/j.ajp.2021.102748

20. Lyyra N., Thorsteinsson E. B., Eriksson C., Madsen K. R., Tolvanen A., Lofstedt P., Valimaa R. The association between loneliness, mental well-being, and self-esteem among adolescents in four Nordic countries. International Journal of Environmental Research and Public Health. 2021; 18(142): art. no. 7405. DOI: https://doi.org/10.3390/ijerph18147405

21. Balin V. D., Hyde V. K., Gerbachevskij V. K. Praktikum po obshhej, jeksperimental'noj i prikladnoj psihologii = Workshop on general, experimental and applied psychology. Edited. by A. A. Krylov, S. A. Manichev. St. Petersburg: Publishing House Piter; 2003. 560 p. (In Russ.)

22. Itzchakov G., DeMarree K. G., Kluger A. N., Turjeman-Levi Y. The listener sets the tone: High-quality listening increases attitude clarity and behavior-intention consequences. Personality and Social Psychology Bulletin. 2018; 44 (5): 762-778. DOI: https://doi. org/10.1177/0146167217747874

23. Glotova G., Wilhelm A. Teacher's self-concept and self-esteem in pedagogical communication. Procedia-Social and Behavioral Sciences. 2014; 132: 509-514. DOI: https://doi. org/10.1016/j.sbspro.2014.04.345

24. Blodgett C., Lanigan J. D. The association between adverse childhood experience (ACE) and school success in elementary school children. School Psychology Quarterly. 2018; 33 (1): 137-146. DOI: https://doi.org/10.1037/spq0000256

25. Kluger A. N., Malloy T. E., Pery S., Itzchakov G., Castro D. R., Lipetz L., Sela Y., Borut L. Dyadic listening in teams: Social relations model. Applied Psychology. $2021 ; 70$ (3): 1045-1099. DOI: https://doi.org/10.1111/apps.12263

26. Hank P., Baltes-Götz B. The stability of self-esteem variability: A real-time assessment. Journal of Research in Personality. 2019; 79: 143-150. DOI: https://doi. org/10.1016/j.jrp.2019.03.004

27. Mageau G. A., Sherman A., Grusec J. E., Koestner R., Bureau J. S. Different ways of knowing a child and their relations to mother-reported autonomy support. Social Development. 2017; 26 (3): 630-644. DOI: https://doi.org/10.1111/sode. 12212

28. Driscoll C., Carter M. The effects of variety of activities on the social interaction of preschool children with disabilities. International Journal of Disability, Development and Education. 2018; 65 (6): 599-613. DOI: https://doi.org/10.1080/1034912X.2018.1446072

29. Lin T.-J., Justice L. M., Emery A. A., Mashburn A. J., Pentimonti J. M. Impacts of teacher-child managed whole-group language and literacy instruction on the depth of preschoolers' social interaction. Early Education and Development. 2017; 28 (4): 457-474. DOI: https://doi.org/ 10.1080/10409289.2016.1246287

30. Dale L. P., Vanderloo L., Moore S., Faulkner G. Physical activity and depression, anxiety, and self-esteem in children and youth: An umbrella systematic review. Mental Health and Physical Activity. 2019; 16: 66-79. DOI: https://doi.org/10.1016/j.mhpa.2018.12.001

31. Wood C., Griffin M., Barton J., Sandercock G. Modification of the Rosenberg scale to assess self-esteem in children. Frontiers in Public Health. 2021; 917: art. no. 655892. DOI: https://doi.org/ 10.3389/fpubh.2021.655892 


\section{Список использованных нсточников}

1. Calafell M. N., Carnicer J. G. Self-esteem in Alumnat de Primåria, from the instrumental ensemble practice // Artseduca. 2019. № 24. P. 15-24. DOI: https://doi.org/10.6035/ Artseduca.2019.24.2

2. Померанцева Т. А. Основные компоненты социализации и индивидуализации младших школьников в современном социокультурном обществе // Вестник Мининското университета. 2018. Т. 6, № 3. С. 8.

3. Ilaltdinova E. Y., Frolova S. V., Lebedeva I. V. Top qualities of great teachers: National and universal // Advances in Intelligent Systems and Computing. 20 18. № 677. P. 44-52. DOI: https://doi.org/ 10.1007/978-3-319-67843-6_6

4. Markova S. M., Sedykh E. P., Tsyplakova S. A., Polunin V. Y. Perspective trends of development of professional pedagogics as a science // Advances in Intelligent Systems and Computing. 2018. № 622. P. 129-135. DOI: https://doi.org/10.1007/978-3-319-75383-6_17

5. Moghaddam M. F., Validad A., Rakhshani T., Assareh M. Child self-esteem and different parenting styles of mothers: A cross-sectional study // Archives of Psychiatry and Psychotherapy. 2017 . № 19 (1). P. 34-42. DOI: https://doi.org/10.12740/APP/68160

6. Wu X. Y., Han L. H., Zhang J. H., Luo S., Hu J. W., Sun K. The influence of physical activity, sedentary behavior on health-related quality of life among the general population of children and adolescents: A systematic review // PLoS ONE. 2017. № 12 (11. Article number e0187668. DOI: https://doi.org/10.1371/journal.pone.0187668

7. Raknes S., Pallesen S., Himle J. A., Bjaastad J. F., Wergeland G. J., Hoffart A., Dyregrov K., Haugland B. S. M. Quality of life in anxious adolescents // Child and Adolescent Psychiatry and Mental Health. 2017 . № 11 (1). Article number 33. DOI: https://doi.org/10.1186/ s 13034-017-0173-4

8. Burenkova O. V., Podturkin A. A. Objective assessment of temperament in temperamentally vulnerable children: Role in the studies on their stress levels // New Directions for Child and Adolescent Development. 2020. № 169. P. 97-115. DOI: https://doi.org/10.1002/ cad. 20330

9. Kolubinski D., Marino C., Nikčevič A., Spada M. A metacognitive model of self-esteem // Journal of Affective Disorders. 2019. № 256. P. 42-53. DOI: https://doi.org/10.1016/j. jad.2019.05.050

10. Немов Р. С. Психология: в 3 кн.: учебник для студентов высш. пед. учеб. заведений. Кн. 3: Психодиагностика. 3-е изд. Москва: ВААДОС, 1999. 640 с.

11. Березин С. В., Аисецкий К. С. Технология формирования социальных навыков: методическое пособие для психологов и социальных педагогов ИТУ. Самара: ИТУ, 1999. $224 \mathrm{c}$.

12. Meland E., Breidablik H. J., Thuen F., Samdal G. B. How body concerns, body mass, self-rated health and self-esteem are mutually impacted in early adolescence: A longitudinal cohort study // BMC Public Health. 202 1. № 21. Article number 496. DOI: https://doi. org/10.1186/s 12889-021-10553-x

13. Yaratan H., Yucesoylu R. Self-esteem, self-concept, self-talk and significant others' statements in fifth grade students: Differences according to gender and school type // Procedia - Social and Behavioral Sciences. 2010. № 2 (2). P. 3506-3518. DOI: https://doi.org/10.1016/j. sbspro.2010.03.543

14. Coluccia A., Ferretti F., Fagiolini A., Pozza A. Quality of life in children and adolescents with obsessive-compulsive disorder: A systematic review and meta-analysis // Neuro- 
psychiatric Disease and Treatment. 2017. № 13. P. 597-608. DOI: https://doi.org/10.2147/ NDT.S 122306

15. Syzdykbayeva A. D., Bainazarova T. B., Aitzhanova E. N. Formation of research competence of the future elementary school teachers - in the process of professional training // International Education Studies. 2015. № 8 (4). P. 200-209.

16. Khan N., Kolumbayeva Sh., Karsybayeva R., Nabuova R., Syzdykbayeva A. Evaluation of the program effectiveness of research competence development in prospective elementary school teachers // International Journal of Environmental and Science Education (IJESE). 2016. № 11 (18). P. 12299-12316.

17. Khan N., Syzdykbayeva A., Kinzhibaeva F., Demesheva G., Abilova O. Organization of teaching practice of future primary school teachers in the context of dual training system: Kazakhstan experience // International Journal of Educational Management. 2018. № 32 (5). P. 942-954.

18. Wang Y., Huebner E. S., Tian L. Parent-child cohesion, self-esteem, and academic achievement: The longitudinal relations among elementary school students // Learning and Instruction. 2021. № 73. Article number 101467. DOI: https://doi.org/10.1016/j.learninstruc. 2021.101467

19. Kim K. M., Kim H., Kim D., Kim J.-W. The analysis of network structure among the depressive symptoms in a clinical sample of children and adolescents // Asian Journal of Psychiatry. 202 1. № 62. Article number 102748. DOI: https://doi.org/10.1016/j.ajp.2021.102748

20. Lyyra N., Thorsteinsson E. B., Eriksson C., Madsen K. R., Tolvanen A., Lofstedt P., Valimaa R. The association between loneliness, mental well-being, and self-esteem among adolescents in four Nordic countries // International Journal of Environmental Research and Public Health. 2021. № 18 (142). Article number 7405. DOI: https://doi.org/10.3390/ ijerph 18147405

21. Балин В. Д., Гайда В. К., Горбачевский В. К. [и др.] Практикум по общей, экспериментальной и прикладной психологии: учеб. пособие / Под общ. ред. А. А. Крылова, С. А. Маничева. Санкт-Петербург: Питер, 2000. 560 с.

22. Itzchakov G., DeMarree K. G., Kluger A. N., Turjeman-Levi Y. The listener sets the tone: High-quality listening increases attitude clarity and behavior-intention consequences // Personality and Social Psychology Bulletin. 2018. № 44 (5). P. 762-778. DOI: https://doi. org/ 10.1177/0146167217747874

23. Glotova G., Wilhelm A. Teacher's self-concept and self-esteem in pedagogical communication // Procedia - Social and Behavioral Sciences. 2014. № 132. P. 509-514. DOI: https://doi.org/ 10.1016/j.sbspro.2014.04.345

24. Blodgett C., Lanigan J. D. The association between adverse childhood experience (ACE) and school success in elementary school children // School Psychology Quarterly. 2018. № 33 (1). P. 137-146. DOI: https://doi.org/10.1037/spq0000256

25. Kluger A. N., Malloy T. E., Pery S., Itzchakov G., Castro D. R., Lipetz L., Sela Y., Borut L. Dyadic listening in teams: Social relations model // Applied Psychology. 2021. № 70 (3). P. 1045-1099. DOI: https://doi.org/10.1111/apps. 12263

26. Hank P., Baltes-Götz B. The stability of self-esteem variability: A real-time assessment // Journal of Research in Personality. 2019. № 79. P. 143-150. DOI: https://doi. org/ 10.1016/j.jrp.2019.03.004

27. Mageau G. A., Sherman A., Grusec J. E., Koestner R., Bureau J. S. Different ways of knowing a child and their relations to mother-reported autonomy support // Social Development. 2017. № 26 (3). P. 630-644. DOI: https://doi.org/10.1111/sode. 12212 
28. Driscoll C., Carter M. The effects of variety of activitics on the social interaction of preschool children with disabilities // International Journal of Disability, Development and Education. 2018. № 65 (6). P. 599-613. DOI: https://doi.org/ 10.1080/1034912X.2018.1446072

29. Lin T.-J., Justice L. M., Emery A. A., Mashburn A. J., Pentimonti J. M. Impacts of teacher-child managed whole-group language and literacy instruction on the depth of preschoolers'social interaction // Early Education and Development. 2017 . № 28 (4). P. 457-474. DOI: https://doi.org/ 10.1080/10409289.2016.1246287

30. Dale L. P., Vanderloo L., Moore S., Faulkner G. Physical activity and depression, anxiety, and self-esteem in children and youth: An umbrella systematic review // Mental Health and Physical Activity. 2019. № 16. P. 66-79. DOI: https://doi.org/10.1016/j. mhpa.2018.12.001

31. Wood C., Griffin M., Barton J., Sandercock G. Modification of the Rosenberg scale to assess self-esteem in children // Frontiers in Public Health. 2021. № 917. Article number 655892. DOI: https://doi.org/10.3389/fpubh.2021.655892

\section{Information about the authors:}

Aigul D. Syzdykbayeva - PhD, Associate Professor, Department of Preschool Education and Social Pedagogy, Abai Kazakh National Pedagogical University; ORCID 0000-0002-48387633; Almaty, Republic of Kazakhstan. E-mail: syzdykbaycva5878@murdoch.in

Raissa K. Izmagambetova - Doctoral Student, Department of Pedagogy and Methods of Primary Education, Abai Kazakh National Pedagogical University; ORCID 0000-0002-34607260; Almaty, Republic of Kazakhstan. E-mail: izmagambetova5878@kpi.com.de

Amina S. Amirova - Dr. Sci. (Pedagogy), Professor, Department of Pedagogy and Methods of Primary Education, Abai Kazakh National Pedagogical University; ORCID 0000-00021771-526X; Almaty, Republic of Kazakhstan. E-mail: amirova5878@uoel.uk

Tursynay B. Bainazarova - Cand. Sci. (Pedagogy), Associate Professor, Head of the Department of Preschool and Primary Education, Kazakh National Women's Teacher Training University; ORCID 0000-0003-1355-040X; Almaty, Republic of Kazakhstan. E-mail: bainazarova5878@unesp.co.uk

Makhabbat K. Sadykova - Cand. Sci. (Pedagogy), Associate Professor, Department of General Pedagogy, Kazakh National Women's Teacher Training University; ORCID 0000-00034392-4062; Almaty, Republic of Kazakhstan. E-mail: sadykova5878@national-univesity.info

Contribution of the authors. The authors equally contributed to the present research.

Conflict of interest statement. The authors declare that there is no conflict of interest.

Received 17.03.2020; accepted for publication 11.08.2021.

The authors have read and approved the final manuscript.

\section{Ннформауия об авторах:}

Сыздыкбаева Айгумь Джуманазаровна - доктор философии, доцент кафедры дошкольного образования и социальной педагогики Казахского национального педагогического университета имени Абая; ORCID 0000-0002-4838-7633; Амматы, Республика Казахстан. E-mail: syzdykbayeva5878@murdoch.in 
Измагамбетова Рапса Кудайбергеновна - докторант кафедры педагогики и методики начального образования Казахского национального педагогического университета имени Aбая; ORCID 0000-0002-3460-7260; Алматы, Республика Казахстан. E-mail: izmagam-betova5878@kpi.com.de

Амирова Амина Сля мхановна - доктор педагогических наук, профессор кафедры педагогики и методики начального образования Казахского национального педагогического университета имени Абая; ORCID 0000-0002-1771-526X; Алматы, Республика Казахстан. E-mail: amirova5878@uoel.uk

Байназарова Турсынай Бейсембековна - кандидат педагогических наук, и.о. доцента кафедры дошкольного обучения и воспитания Казахского национального женского педагогического университета; ORCID 0000-0003-1355-040X; Алматы, Республика Казахстан. E-mail: bainazarova5878@unesp.co.uk

Садыкова Махаббат Каримовна - кандидат педагогических наук, и.о. доцента кафедры общей педагогики Казахского национального женского педагогического университета; ORCID 0000-0003-4392-4062; Алматы, Республика Казахстан. E-mail: sadykova5878@ na-tional-univesity.info

Вжлад соаеторое. Авторы внесли равный вклад в подготовку статьи.

Ннформауия о конфликте интересов. Авторы заявляют об отсутствии конфликта интересов.

Статья поступила в редакцию 17.03.2020; принята в печать 11.08.2021.

Авторы прочитали и одобрили окончательный вариант рукописи. 